\title{
PERANCANGAN VIDEO PROMOSI SEKOLAH MUSIK INDONESIA DI KOTA SURABAYA
}

\author{
Percy Harris Anugerah, \\ Angga Hendrawan, \\ Christyan Budi Susilo. \\ Institut Informatika Indonesia (IKADO), Surabaya. \\ Percy.harris92@gmail.com
}

\begin{abstract}
Abstrak
Sekolah Musik Indonesia merupakan salah satu sekolah musik yang berkembang di Indonesia dan khususnya di kota Surabaya. Selama 3 tahun terakhir mengalami naik-turun murid yang cenderung tidak stabil. Hal tersebut bisa terjadi dikarenakan kurang efektifnya media promosi yang dilakukan. Kemudian dari hasil analisis ditemukan bahwa video promosi merupakan sarana terbaik untuk dapat meningkatkan jumlah murid. Video menggunakan konsep "every child is different" yang merupakan salah satu moto Sekolah Musik Indonesia. Video promosi ini didistribusikan melalui media yaitu Above the line, Below the line and Through the line. Oleh karena itu sebagai sarana yang efektif untuk meningkatkan jumlah murid, perlu dibuat video promosi Sekolah Musik Indonesia di kota Surabaya yang menarik, informatif serta persuasif yang terlihat dari informasi yang disampaikan melalui testimoni dari pihak murid dan orang tua murid dengan adanya video yang menujukan program serta kelas-kelas yang dimiliki. Video ini juga menggunakan teknik pengambilan gambar yang dapat memudahkan audiens untuk dapat menikmati setiap informasi yang diberikan seperti halnya eye level, high angle dan pengambilan frame close up, medium close up, mid shot, and over shoulder shot. Sehingga mampu memberikan pengaruh yang baik bagi Sekolah Musik Indonesia dan juga bagi penulis.
\end{abstract}

Katakunci: Videografi, Video promosi, Sekolah Musik Indonesia

\begin{abstract}
Sekolah Musik Indonesia is one school of music that developed in Indonesia and particularly in the city of Surabaya. Over the last 3 years experienced ups and downs of students who tend to be unstable. The cause of the lack of effective from media campaign conducted. The promotional video selected as one of the media campaign which is used to boost the number of students. Video used the concept of "every child is different", which is moto from School of Music Indonesia. Promotional videos are distributed through the media that is above the line, below the line, and the line trough. Therefore an effective means for increasing the number of students, the need for a
\end{abstract}


promotional video Sekolah Musik Indonesia in Surabaya interesting, informative and persuasive seen from the information submitted through the testimony of the students also the parents and then the existence of a video showing the programs and classes. It also uses the video shooting techniques can be easy for the audience to be able to enjoy any of the information provided as well as eye-level, high angle, and the decision-frame close-ups, medium close-up, mid shot, and over-shoulder shot. So as to provide a good influence for Sekolah Musik Indonesia and also for writer.

Keywords: Videography, Video promotion, Sekolah Musik Indonesia..

\section{PENDAHULUAN}

Musik memiliki hubungan erat dengan manusia dan alam semesta. Tidak dapat dipungkiri bahwa setiap orang di dunia pasti pernah mendengar dan menikmati musik dalam kehidupan sehari-hari. Musik sudah ditemukan mulai abad ke-2 dan berkembang dengan pesat sehingga tidak hanya digunakan untuk pemujaan kepada Dewa atau Tuhan namun juga digunakan sebagai sarana hiburan, bahkan di komersilkan dalam berbagai bentuk.

Perkembangan musik sendiri tersebar secara luas keseluruh Dunia, begitupula di Indonesia yang merupakan negara berkembang dan memiliki sektor industri dalam dunia ekonomi kreatif yang sedang digalakkan saat ini. Hal tersebut sangat menguntungkan dan berdampak bagi Indonesia, terlihat dari maraknya para musisi dari berbagai kota di Indonesia, salah satunya kota Surabaya yang melahirkan musisi papan atas. Surabaya merupakan salah satu kota terbesar ke-2 di Indonesia dengan perkembangan yang terbilang sangat pesat. Hal ini terlihat dari masyarakat yang mulai sadar akan mutu pendidikan. Meningkatnya mutu pendidikan membuat munculnya peluang bisnis baru di banyak bidang salah satunya bidang musik, terlihat dari banyak bermunculan kursus musik di kota Surabaya. Sekolah Musik Indonesia merupakan salah satu kursus musik yang ada di kota Surabaya. Sekolah Musik Indonesia sudah berdiri sejak tahun 2010. Sampai saat ini SMI telah memiliki 2 cabang di kota Surabaya yaitu SMI Ngagel dan SMI Graha Famili. Marak bermunculan tempat kursus musik di kota Surabaya menyebabkan meningkatnya persaingan. Hal ini berpengaruh terhadap jumlah murid dari Sekolah Musik Indonesia yang fluktuatif. Fenomena diatas berdasarkan 
data-data yang dijumpai di lapangan dan data rekap nilai jumlah murid Sekolah Musik Indonesia dari tahun 2013 hingga 2015.

Berdasarkan permasalahan dari fenomena diatas, peneliti telah melakukan wawancara mendalam dengan pihak manajemen Sekolah Musik Indonesia di wilayah Jawa Timur serta membagikan kuesioner kepada guru, orang tua, murid dan masyarakat awam yang dapat dijabarkan yaitu kurang efektifnya media promosi yang dilakukan oleh Sekolah Musik Indonesia di kota Surabaya. Dari pernyataan tersebut dapat disimpulkan bahwa perlu adanya perancangan media promosi yang efektif untuk mendukung promosi. Video promosi dipilih sebagai media promosi yang efektif sehingga meningkatkan jumlah murid di Sekolah Musik Indonesia di kota Surabaya.

\section{KAJIAN TEORI}

\section{Teori Promosi}

Menurut Richard J. Semenik (2002: 15) promosi adalah proses komunikasi dalam pemasaran sebuah merek dari produk/ jasa, ide atau pribadi seseorang, digunakan agar sasaran komunikasi memiliki predisposisi atau tendensi positif kepada merek. Promosi bertujuan untuk 1) Memperkenalkan produk seluas mungkin; 2) Menyusun produk agar tampil semenarik mungkin; 3) Menyampaikan isi pesan secara menarik, tanpa harus berbohong isi pesan tersebut harus membangkitkan kesadaran dan hasrat yang kuat sebagai saingan terhadap pesanpesan promosi lainnya.

Promosi memiliki prinsip-prinsip promosi yaitu product (produk), price (harga), place (tempat, lokasi), public relation (kehumasan), positioning dan pemasaran Viral. Promosi juga memiliki berbagai jenis promosi yaitu Above the line merupakan promosi media cetak yang menggunakan media seperti televisi, radio, koran, internet dimana para advertiser membayar agensi periklanan sebagai penempatan iklan tersebut. Bellow the line yaitu promosi yang meliputi sponsorship, penempatan produk, sales promotion, merchandise, direct mail, personal sellingn dan juga public relation. Through The Line merupakan kegiatan komunikasi pemasaran dari segi tujuan komunikasi, dalam proses brand building 
terdapat dua tahap penting yang cukup signifikan yaitu tahap Awareness+Image building dan tahap Interest, Trial dan Loyalty building” (Maulana, 2008).

\section{Teori Videografi}

Video berasal dari kata Latin yang berarti saya lihat. Video adalah teknologi pemrosesan sinyal elektronik yang mewakilkan gambar bergerak. Aplikasi umum dari teknologi video adalah televisi. Video juga dapat digunakan dalam aplikasi teknik, industri, keilmuan, produksi dan keamanan. Istilah video juga digunakan sebagai singkatan videotape, perekam video dan pemutar video (Binanto, 2010:10).

Video atau gambar bergerak adalah data digital yang terdiri dari beberapa gambar. Istilah video biasanya mengacu pada beberapa format penyimpanan gambar bergerak. Terbagi menjadi dua yaitu video analog (VHS dan Betamax) dan video digital (DVD, Quicktime, dan MPEG-4). Video dapat direkam dan ditransmisikan dalam berbagai media fisik pada pita maknetik ketika direkam sebagai Pal atau NTSC signal elektrik dengan video kamera atau MPEG-4 ketika direkam menggunakan kamera digital. Gambar tersebut dapat ditemui di kehidupan sehari-hari seperti saat melihat benda-benda yang bergerak. Melalui sebuah teknologi (kamera), gambar-gambar bergerak dapat disimpan pada sebuah data digital (video). Untuk dapat menampilkan data digital (video) ini maka diperlukan sebuah alat untuk mengubah data digital menjadi analog misalnya televisi dan monitor (Purnama, 2013: 14).

\section{METODE PENELITIAN}

Data yang telah dikumpulkan oleh penulis diperoleh dari berbagai narasumber yang hasilnya untuk mendukung dalam proses perancangan. Pencarian data dilakukan melalui metode sebagai berikut: 1) Mengidentifikasi fenomena dan permasalahan yang ada; 2) Penyebaran kuesioner untuk mengetahui keinginan audiens serta menemukan permasalahan; 3) Wawancara dengan Regional Manager Sekolah Musik Indonesia wilayah Jawa Timur; 4) Wawancara dengan Branch Manager Sekolah Musik Indonesia cabang Graha Famili; 5) Wawancara dengan Marketing SMI Ngagel; 6) Studi kompetitor serta komparator. Studi kompetitor dilakukan terhadap beberapa video promosi dari tempat kursus atau sekolah musik 
yaitu Yamaha Music School Indonesia dan Ahmad Dhani School of Rock. Studi komparator dilakukan pula terhadap beberapa video promosi tempat kursus yaitu Jogja Audio School dan Milkin University USA dan Berklee College of Music; 7) Studi Literatur dan teori yang berhubungan metode penelitian berisi tentang desain penelitian atau rancangan penelitian, subjek penelitian, teknik pengumpulan data, instrumen penelitian serta teknik analisis data.

\section{HASIL DAN PEMBAHASAN}

\section{Proses Perancangan}

Proses perancangan didapatkan dari penyebaran kuesioner kriteria desain yang disaring sehingga menjadi konsep/ desain. Kemudian berdasarkan penyebaran tersebut akan dilanjutkan dengan menentukan positioning dari video promosi dan mendapatkan keyword serta konsep yang diinginkan yang dibuat berdasarkan skema berikut ini:

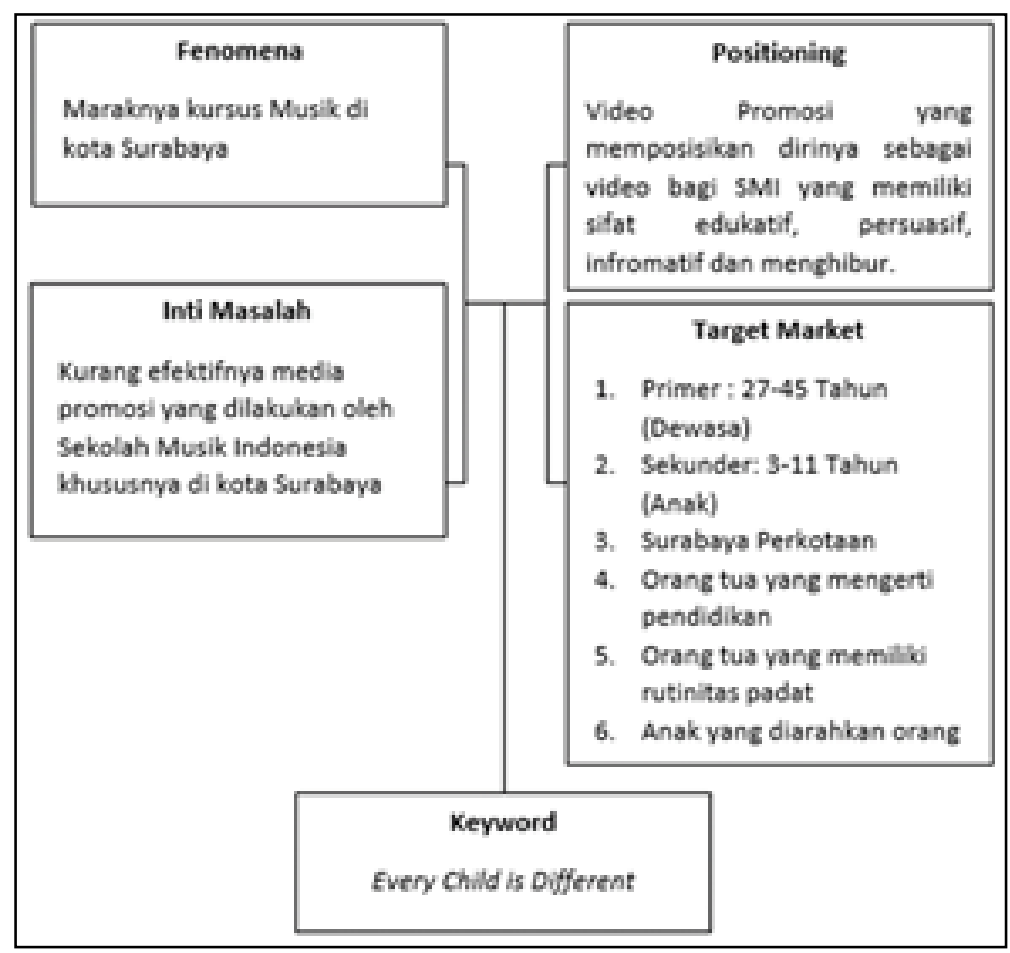

Gambar 1. Skema Keyword Sumber: Dokumentasi Penulis 
Pengertian ini bertujuan agar video promosi yang dibuat memiliki daya tarik kepada audiens dan memiliki sisi informatif, edukatif dan persuasif, serta menghibur melalui keyword yang dimiliki yaitu "every child is diffrerent" dan dalam video tersebut akan memunculkan setiap karakter dari anak-anak yang ada bahwa mereka memiliki karkter dan kepribadian yang berbeda-beda. Dari perbedaan tersebut lahirlah sesuatu yang unik dan dikemas melalui video promosi yang dapat menjadi daya tarik bagi para audiens untuk dapat bergabung dengan Sekolah Musik Indonesia.

\section{Proses Desain}

Video promosi ini dibagi menjadi 3 versi yaitu versi company profile, TVC, dan iklan pendek/ Ad. Dalam pembuatan video promosi ini diperlukan sebuah storyboard yang bertujuan untuk dapat mengetahui bagaimana gambaran sebuah video akan dibuat. Berikut merupakan storyboard dari ke-3 versi video promosi dari Sekolah Musik Indonesia.

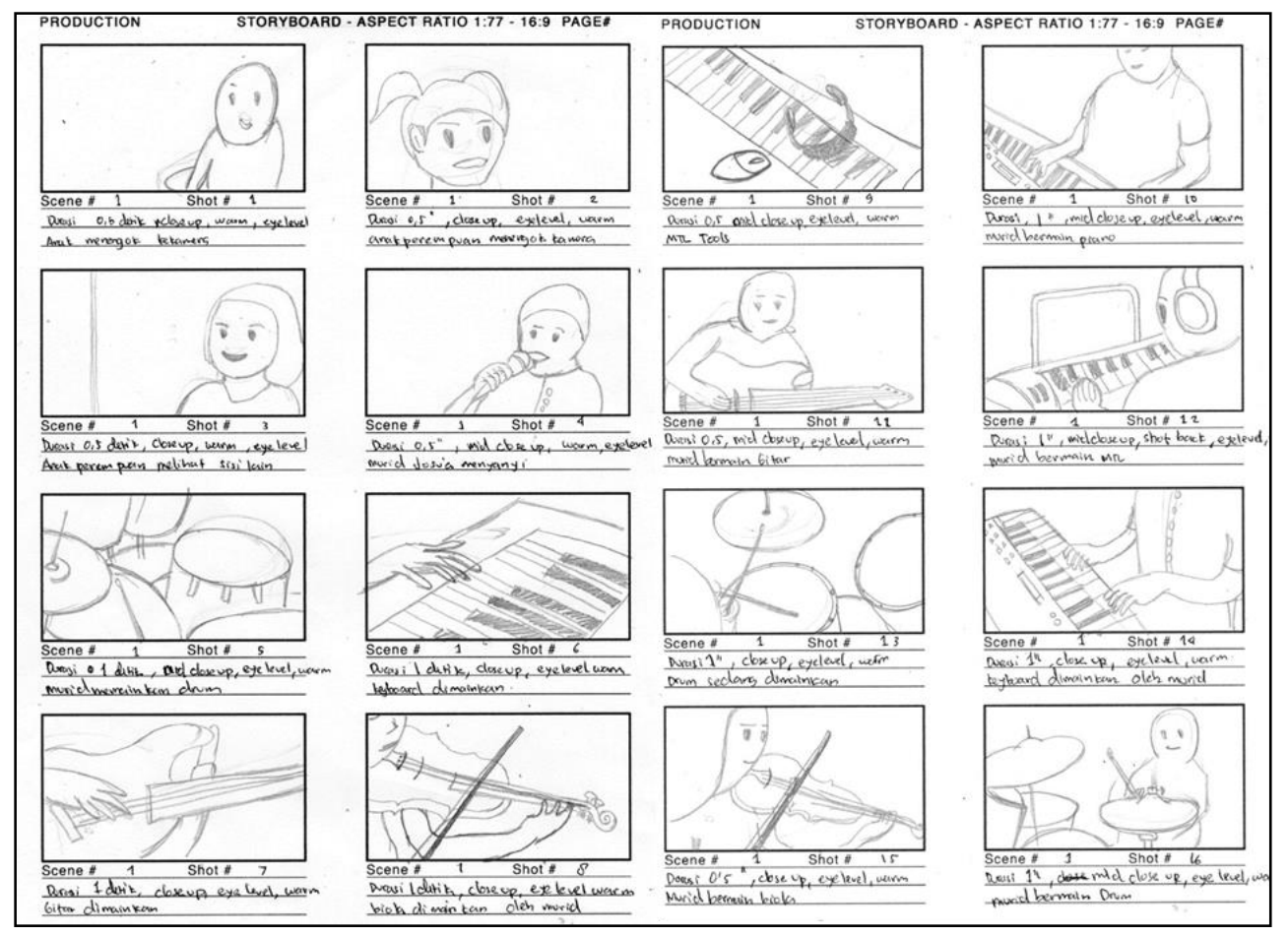

Gambar 2. Potongan Sketsa Storyboard TVC

Sumber: Dokumentasi Penulis 


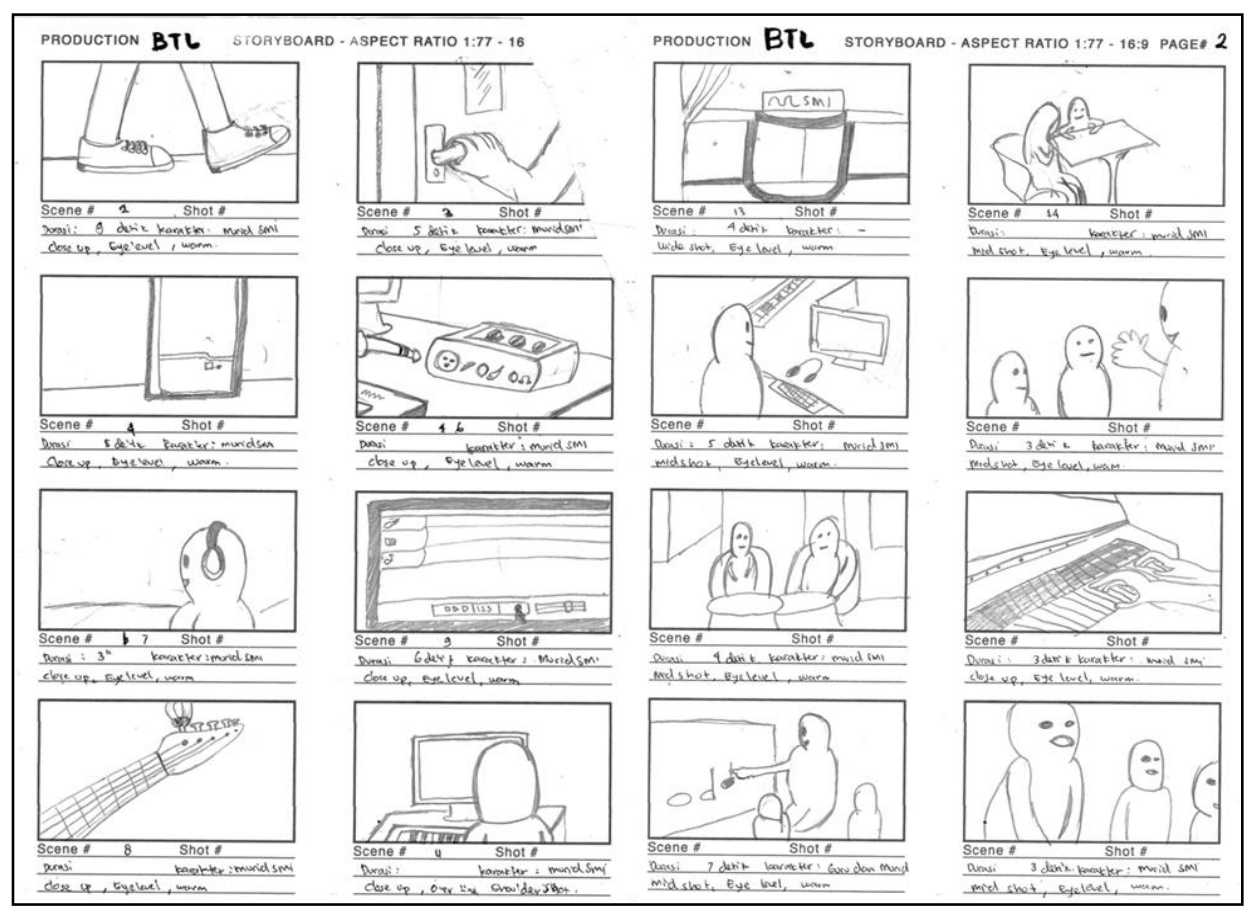

Gambar 3. Potongan Sketsa Storyboard Company Profile

Sumber: Dokumentasi Penulis

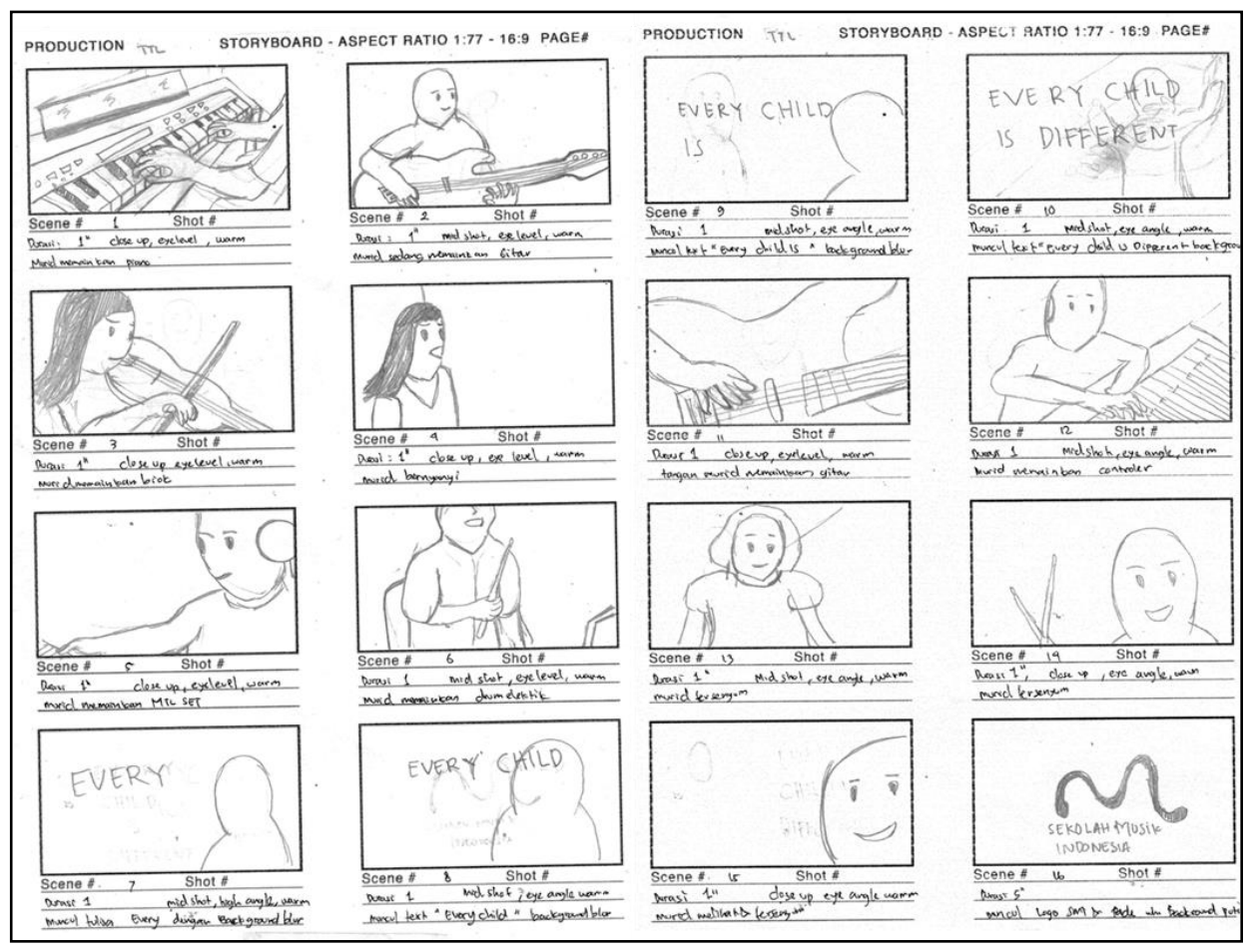

Gambar 4. Potongan Sketsa Storyboard Iklan pendek

Sumber: Dokumentasi Penulis 


\section{Desain Akhir}

Media utama dalam perancangan ini adalah video promosi Sekolah Musik Indonesia di kota Surabaya dengan resolusi 1280 x 720 pixel. Video promosi ini memiliki konsep "every child is different" yang bertujuan untuk menarik minat para konsumen terutama kalangan menengah ke atas di kota Surabaya. Sesuai dengan konsep awal yang disajikan, video promosi ini menonjolkan sisi anak-anak dan karakter yang mereka miliki terutama saat belajar di sekolah musik Indonesia.

Video promosi ini mempunyai tiga versi dan memiliki penerapan pada tiga lini media yaitu Above the line, Below the line, Trough the line. Dalam video tersebut dibagi menjadi tiga versi yaitu Company profile di khususkan untuk Below the line media dengan durasi maksimal 6 menit. Dan untuk TVC dikhususkan untuk Above the line media dengan durasi 1 menit, serta Iklan pendek ( $a d)$ untuk Through the line media dengan durasi 15 detik.

Berikut adalah cuplikan dari desain akhir media utama Video Promosi Sekolah Musik Indonesia:

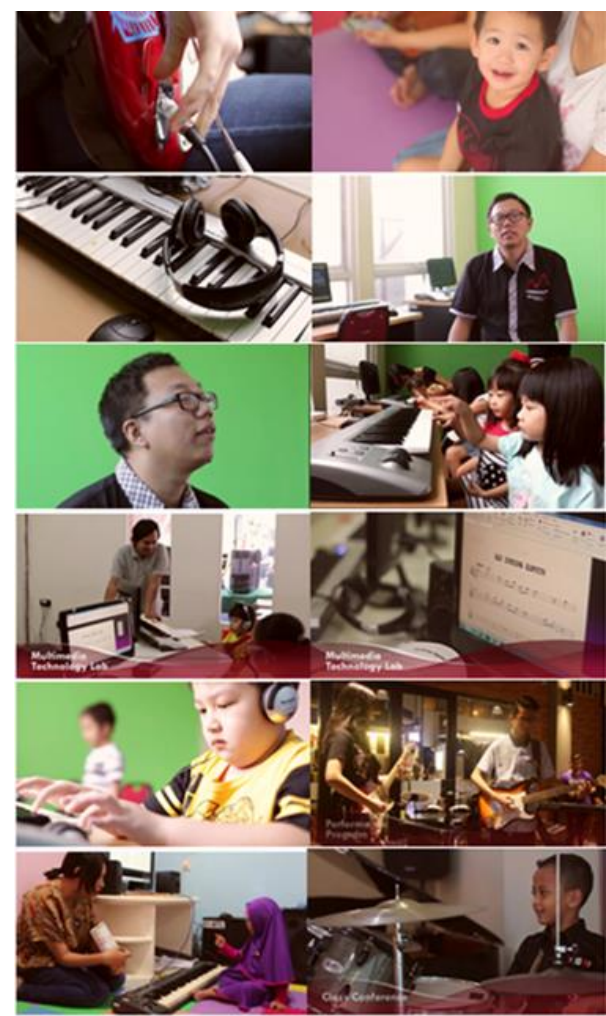

Gambar 5. Cuplikan video company profil

Sumber: Dokumentasi Penulis 


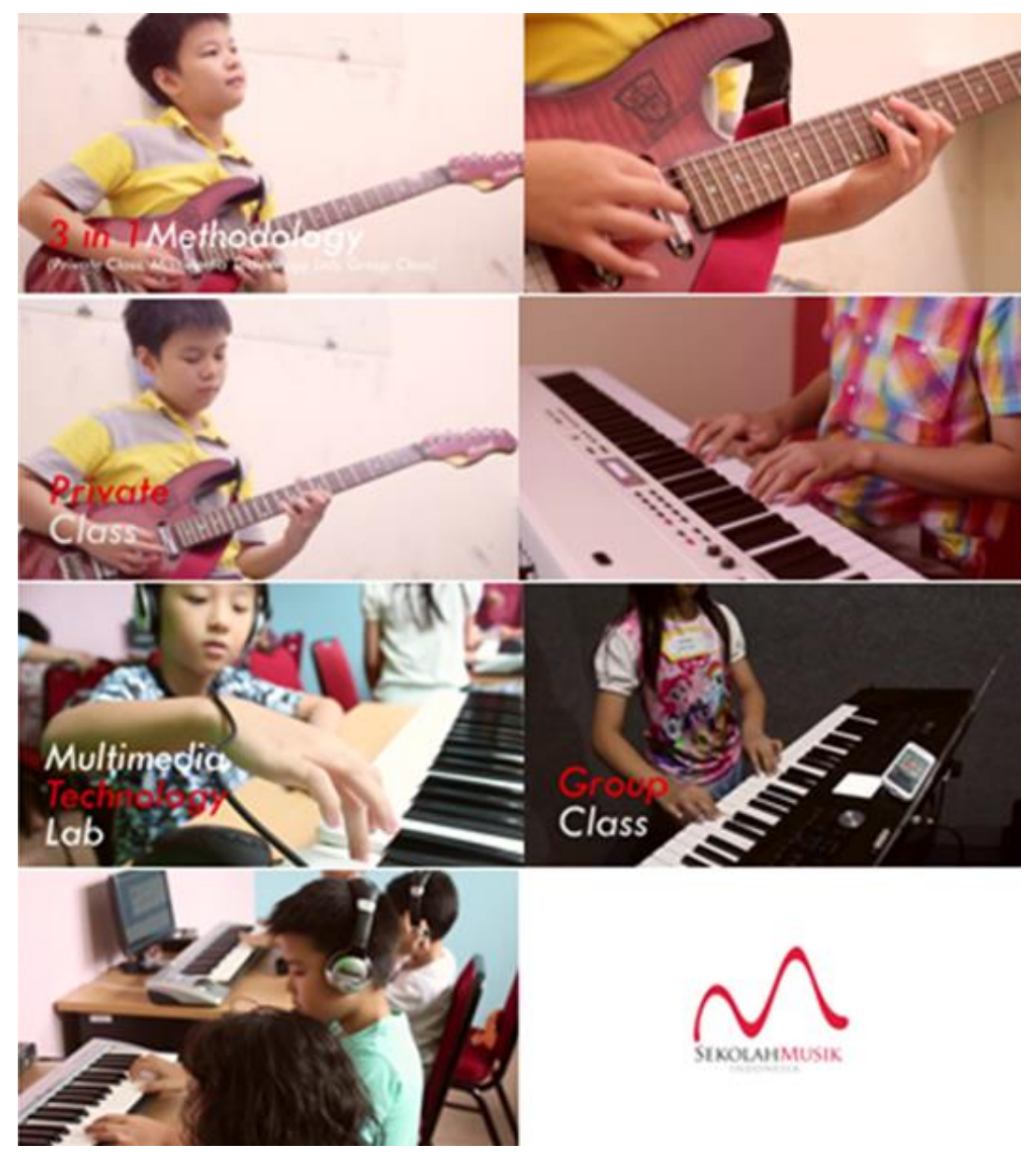

Gambar 6. Cuplikan video promosi TVC

Sumber: Dokumentasi Penulis

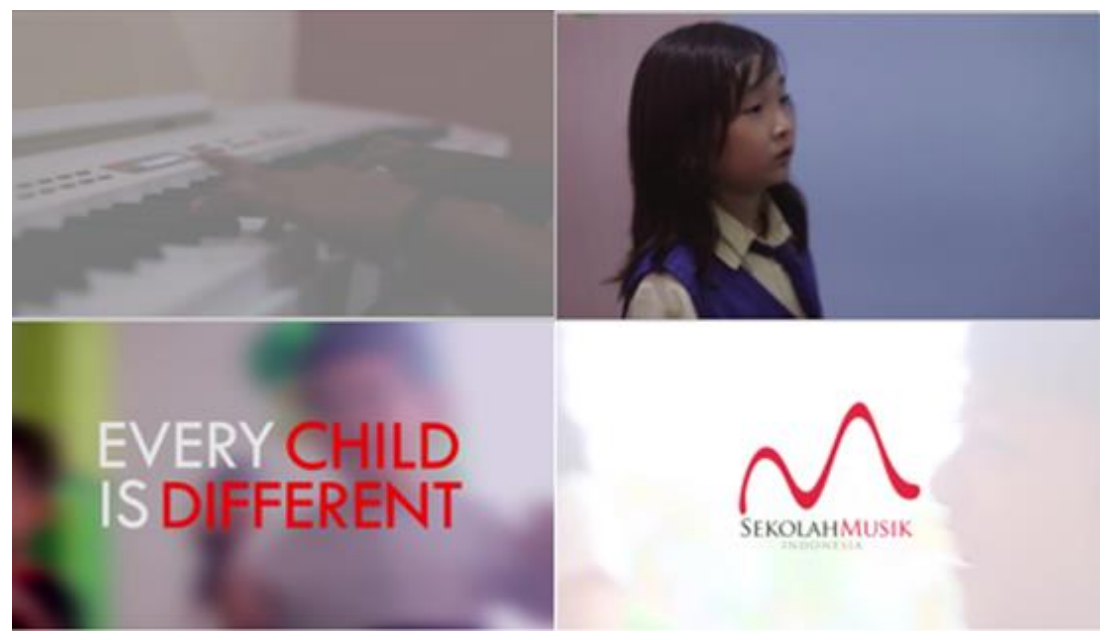

Gambar 7. Cuplikan video iklan pendek/ ad

Sumber: Dokumentasi Penulis 
Selain media utama, perancangan media ini dilengkapi dengan media pelengkap. Media pelengkap dalam perancangan ini adalah banner, brosur, booklet, serta mockup komputer dan handphone. Tujuan dari adanya media pelengkap ini untuk mendistibusikan video promosi yang dimiliki oleh Sekolah Musik Indonesia sehingga dapat meningkatkan jumlah murid dari Sekolah Musik Indonesia.

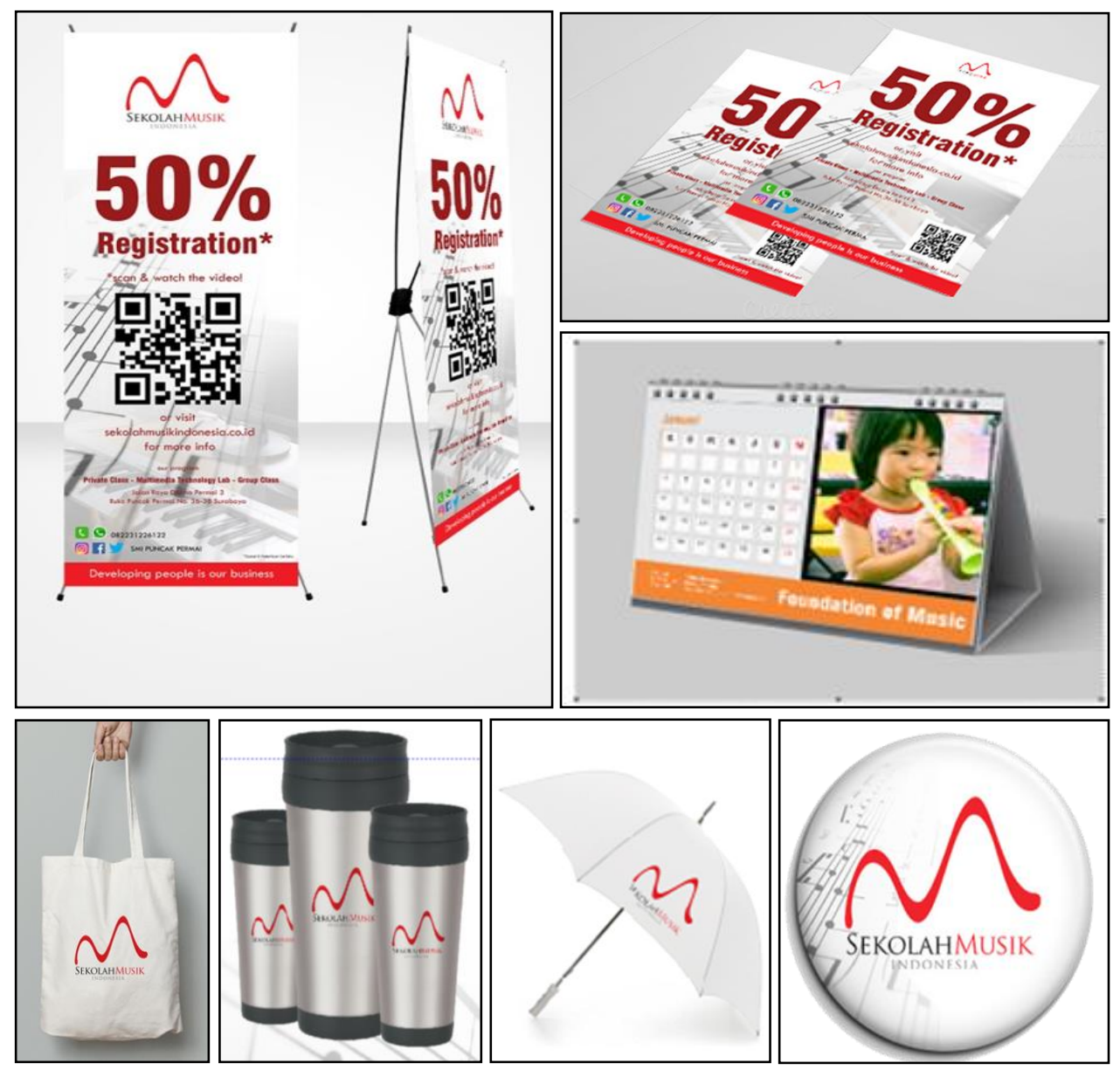

Gambar 8. Media Pelengkap

Sumber: Dokumentasi Penulis 


\section{SIMPULAN DAN SARAN}

\section{Simpulan}

Pengunaan media promosi yang sesuai dengan kebutuhan promosi sebuah perusahaan dapat meningkatkan pendapatan dari sebuah perusahaan. Hal ini dilakukan untuk meningkatkan jumlah murid dari Sekolah Musik Indonesia khususnya di kota Surabaya. Dikarnakan kurangnya penggunaan media video promosi yang mengakibatkan kurang efektifnya pemasukan sehingga diputuskan melalui riset kuesioner, identifikasi masalah dan wawancara mendalam dengan pihak Sekolah Musik Indonesia bahwa video promosi merupakan salah satu media yang perlu untuk dirancang agar dapat meningkatkan jumlah murid dari Sekolah Musik Indonesia. Dari ide video promosi ini lahirlah 3 tipe video promosi yaitu Company profile, TV Commercial dan Iklan pendek yang akan digunakan dan didistribusikan untuk dapat meningkatkan kinerja dari media promosi yang dimiliki oleh Sekolah Musik Indonesia. Ke-3 video tersebut diharapkan dapat mendongkrak jumlah murid dari Sekolah Musik Indonesia khususnya yang ada di kota Surabaya. Dan dapat bertahan dengan semakin berkembang dengan lebih baik lagi. Diharapkan video ini dapat bermanfaat bagi Sekolah Musik Indonesia dan Institut Informatika Indonesia (IKADO), Surabaya untuk dapat dijadikan bahan acuan atau referensi dalam pembuatan karya-karya videografi selanjutnya.

\section{Saran}

Konsep merupakan salah satu hal yang paling penting dalam pembuatan sebuah video, baik itu video promosi, company profile ataupun video yang lainnya. Hal ini yang harus diperhatikan untuk setiap orang yang ingin membuat sebuah video yang memiliki manfaat. Untuk kedepannya diharapkan agar semua orang yang ingin membuat sebuah video harus menemukan konsep yang tepat terlebih dahulu sebelum melanjutkan langkah berikutnya. Laporan ini diharapkan dapat membantu khususnya para mahasiswa dan mahasiswi Institut Informatika Indonesia (IKADO) Surabaya untuk dapat dijadikan referensi dalam pembuatan karya-karya selanjutnya, sehingga dapat bermanfaat dan menciptakan sebuah video yang terkonsep dengan rapi dan dapat diterima oleh semua orang. 


\section{DAFTAR PUSTAKA}

Binanto, Iwan. (2010). Multimedia Digital-Dasar Teori dan Pengembangannya. Yogyakarta: Andi.

Maulana, Amalia E. (2008). The End of the line: Mengakhiri istilah ATL vs BTL. Diakases pada tanggal 03 Mei 2016 dari http://amaliamaulana.com/populararticle/the-end-of-the-line-mengakhiri-penggunaan-istilah-atl-vs-btl/

Purnama, Bambang Eka. (2013). Konsep Dasar Multimedia. Yogyakarta: Graha Ilmu.

Sememik, Richard J. (2002). Promotion\&Integrated Marketing Communication. Singapore: South-Western College Publishing. 